brazilianpoliticalsciencereview

ARTICLE

\title{
Divergences Between New Patterns of Global Trade and
}

Brazil/Mercosur*

\author{
Eduardo Viola \\ Universidade de Brasilia, Brazil \\ Jean Santos Lima \\ Universidade de Brasilia, Brazil
}

\begin{abstract}
Although integration has been a part of South American discourse for decades, the level at which it is actually promoted remains far from that which is observed in dynamic production and trading centers. Given transformations in global trade, the phenomenon of global value chains is, in fact, very regionalized. We ask whether the trading pattern of Mercosur countries is aligned with approaches based on regional value chain, and if not, how it differs and why. In our evidence and analysis, we primarily use traditional gross trade data and Trade in Value Added (TiVA) indicators, and we look more at countries' profiles. We show that there has been a decrease in Brazilian trade with Mercosur, with manufactured exports being the main reason for the decline. We indicate that, in addition to the effect of China in the 2000s, there has been a structural movement of Mercosur economies, mainly regarding Brazil, which supports a hypothesis of primarization or deindustrialization. Our results show that Brazil and Argentina are both relatively closed to foreign trade, as well as global and regional value chains, which makes them even more poorly integrated with one another. This reinforces what we call Mercosur's 'introspective' model of integration, making it less outward-oriented, which is divergent with what is observed when regional value chains are encouraged.
\end{abstract}

Keywords: Mercosur; trade; competitiveness; value chains; integration.

(*) http://dx.doi.org/10.1590/1981-3821201700030001

For data replication, see www.bpsr.org.br/files/archives/Dataset_Viola_Lima

Authors are grateful to CNPq and CAPES for their respective grants. The authors also would like to thank the valuable comments from anonymous BPSR reviewers.

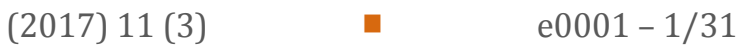


I

n the 2000s, South America was experiencing its best economic performance in 40 years, with reasonable rates of growth and macroeconomic stability, and important social advances such as the reduction of poverty thanks to a combination of domestic reforms and a favorable international context (ECLAC, 2014). However, the region seems to have advanced little in international competitiveness and export sophistication, continuing far behind the world's great centers of production (ECLAC, 2014; HERNÁNDEZ et al., 2014). The catch is that, in the medium- and long-term, this delay may even threaten the socio-economic achievements of the last decades, especially given the complex challenges of globalization, the digital revolution, and an international context that is less favorable for exporting.

At the same time, the region still needs large-scale productive integration, which could be a boost to regional development despite the enormous logistic, infrastructural, and political challenges to be faced. In this sense, Brazil - as the largest country in the region in terms of area, population, and economy- officially made regional integration its top foreign policy priority in the 2000s. However, the literature on the integration of production networks, as well as our analysis of empirical evidence, show that Mercosur, the most ambitious bloc of economic and political integration in the world among nondeveloped countries, does not resemble value chains focused on encouraging joint global competitiveness. Our emphasis is on the cases of Brazil and Argentina, the most industrialized countries in South America.

A series of structural changes in the global economy in recent decades, combined with political and economic decisions, has produced new patterns of international trade that require states to readapt their instruments of regional integration. Some of these standards are global and regional value chains, outsourcing, and offshoring, among other concepts. What these concepts have in common is the fragmentation of production processes into various stages dispersed throughout various different countries and regions. They also result in the asymmetry of gains, such as financial gains, technological spillovers, employment, or value added, according to each country's specialization within a production chain.

On the one hand, some studies associate increasing value-added trade participation with greater technology absorption, wider market access and productivity gains (BALDWIN, 2011; CANUTO, 2014; OECD, 2013; OECD, WTO, and UNCTAD, 2013; WORLD BANK, 2015). On the other hand, caution should be exercised concerning 
strategies of engagement, whether in regional or global value chains. The benefits of value chains are asymmetric, and the most beneficial steps tend to be focused on intangible services and the production of higher value-added products. Likewise, ongoing technological revolutions can make global value chains even more regional, which tends to increase the importance of joint strategies with neighboring countries.

Insofar as Mercosur is an ambitious integration bloc, we ask whether the trading pattern of Mercosur countries aligns with the regional value-chain-based approach. If not, then how does it differ and why? We show that there has been a decrease in Brazil's trade with Mercosur, with manufactured exports being the main reason for the decline. We show that, besides the effect of China in the 2000s, there has been a structural movement of Mercosur economies, mainly regarding Brazil, which supports a hypothesis of primarization or deindustrialization. We stress that the logic of value chains sees regional integration as an important source of industrialization, as has been the case with the three major regions that have already become integrated: the European Union, North America, and East Asia. Our results, however, show that Brazil and Argentina are both relatively closed to foreign trade, as well as global and regional value chains, making them even more poorly integrated with one another. These facts reinforce what we call Mercosur's 'introspective' model of integration, making it less outward-oriented, which is divergent with what is observed when regional value chains are encouraged. We also emphasize that the current Mercosur situation represents some threats to long-term integration, and its members are drifting even farther away from the manufacturing competitiveness of advanced economies.

The article is divided into five sections (not including this introduction). First, we briefly describe the relation between regional value chains and industrialization. Second, we provide an overview of Mercosur's performance, particularly the recent decrease in Brazil's trade with other countries in South America and Mercosur, emphasizing manufacturing exports and Mercosur countries' export baskets. Third, we show evidence of Brazil and Argentina closing themselves to foreign trade, and analyze their distinctiveness regarding value chain participation, shedding light on some hidden patterns. Fourth, we summarize our findings, relating them to the literature and analyzing Mercosur as a model of introspective integration. Finally, we provide our conclusion. 


\section{Regional value chains and industrialization}

The fragmentation and dispersion of international production could only be globalized by the telecom and technology revolutions, using decreasing transport, transaction, and communications costs (BALDWIN, 2011). The continuity of outsourcing and the transnationalization of activities by firms and governments gave rise to value chains at the global and regional levels. According to this logic, countries engaging in global and regional value chains specialize in outsourcing and transnationalization, aware of the high cost of producing goods entirely within their borders.

But the gains from value chains are asymmetrical, and greater benefits come from both the beginning and the end of the production process, as shown in the 'smiling curve' in Figure 01, which represents the production of electronics or machinery. These extremes concentrate advanced services, which could be applied to the manufacturing process, and have scale gains from expanding production, and are also tradable. Nevertheless, quality services require medium- and high-skilled human labor, as well as a business environment that enables information, technology, and research firms to expand (OECD, 2013; STURGEON et al., 2013).

Figure 01. The smiling curve: value-added along the GVC

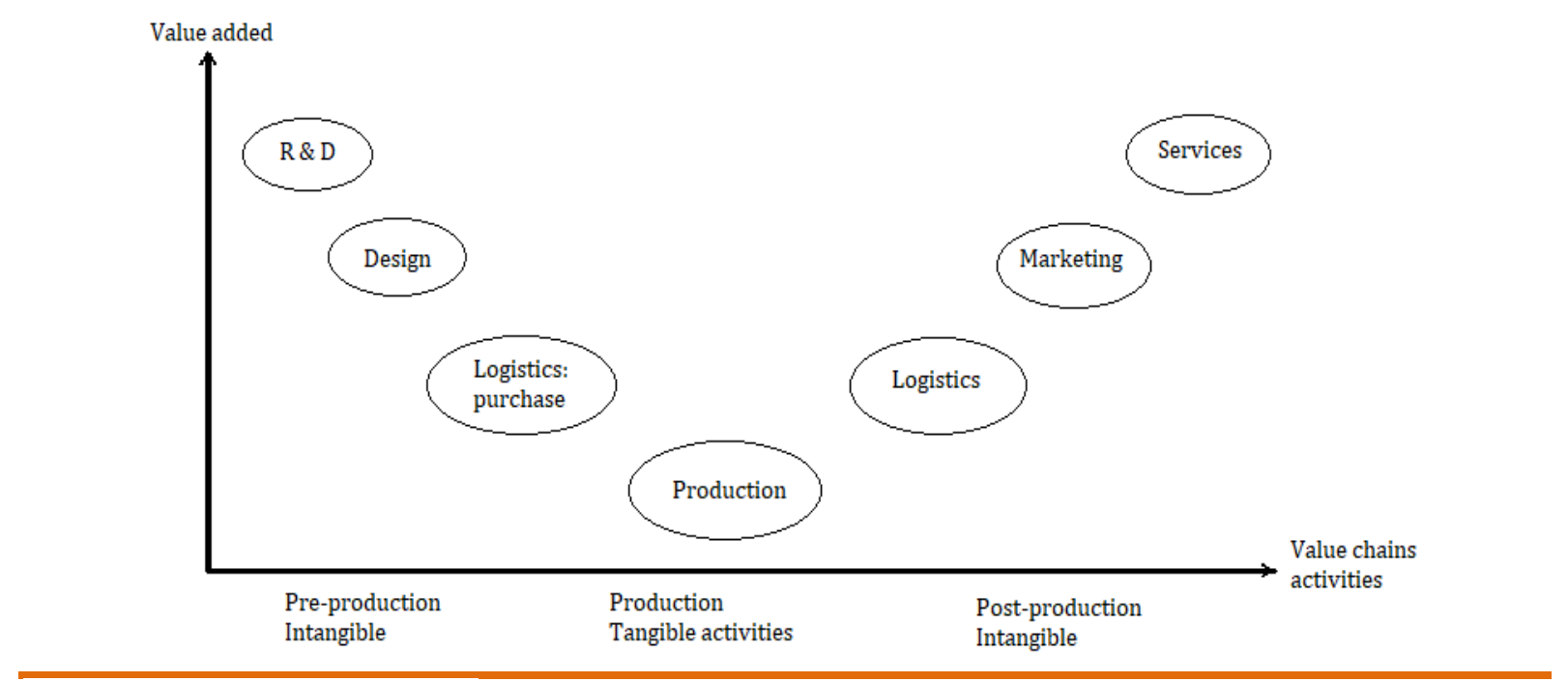

Source: OECD (2013, p. 214).

According to the OECD (2013), the way in which value chains affected trade policies was unique in history. Protectionism became costlier, as tariffs are cumulative when intermediate goods are exchanged across borders countless times. As a result, more expensive inputs discouraged countries and their firms from becoming inserted into a transnational value chain (OECD, 2013). In this sense, some regions recognized the cost 
of protectionism decades ago. A common fact within practically the entirety of East Asia is the low protection level for semi-processed products, which enabled production complementarity (BAUMANN, 2013; ESTEVADEORDAL, BLYDE, and SUOMINEN, 2013). Moreover, value chains change perceptions about development and business strategies, as well as industrial, commercial, and foreign policy options.

These trade patterns are an opportunity for the industrial development of lateindustrializing countries, such as Brazil because they allow emerging countries less time to catch up to developed countries (OECD, WTO, and UNCTAD, 2013). Brazil has niches of global competitiveness, such as the production of medium-sized aircraft, agribusiness, iron ore, and oil exploration in deep waters. But the sustainability of these (and other) sectors depends on a recognition of the opportunity to foster processes of productive complementarity and advances in service areas.

Brazil has three options regarding the challenges and opportunities facing these international value-added standards, and all of them are complex. The first is to create its own chains, a very difficult challenge given Brazil's deficit in infrastructure and technology; it would need decades to build a solid chain. In addition, this option tends to neglect the opportunities of spreading production internationally, such as lower production costs, and more competitiveness. The second option is to join the existing chains or to improve its position in chains in which Brazil is already a member. The third is to build competitive production chains at the regional level. We believe that the third option, combined with elements of the first two, tends to have more gains over time because this was the path followed by other nations in North America, Western Europe, and especially East Asia (BALDWIN, 2011).

Global value chains are, in fact, a very regionalized phenomenon. The 'geographical component' is a common feature of value chains; countries often develop trade at the regional level through mechanisms such as productive complementarity, preferential trade agreements, and investment agreements (BALDWIN, 2013; ELMS and LOW, 2013). As demonstrated by Estevadeordal, Blyde, and Suominen (2013), physical distance between countries reduces the chances of them forming a productive chain, and in turn, substantially decreases foreign added value. As per the authors' empirical model, "a $10 \%$ increase in distance reduces the average foreign value added by about $67 \%$ ", as the "participation in the same preferential trade agreement (PTA) increases the average foreign value by 15\%" (ESTEVADEORDAL, BLYDE, and SUOMINEN, 2013, pp.15). 
Therefore, it would be in the interest of countries that are far from the main centers of the global value chains (GVC) to seek to develop their own regional value chains, especially when considering the high cost of putting together 'full' national value chains (unless one can create prospective positive visions of large-scale automation and reshoring).

The $21^{\text {st }}$-century literature draws attention to this aspect in the form of regional integration networks in terms of production and trade. It usually defines the central country as a hub and smaller partners as spokes (BALDWIN, 2011; BAUMANN, 2013; IAPADRE and TAJOLI, 2013). The U.S. has a central position in North American value chains and global service exports. In the European Union, Germany plays a central role as a hub, alongside France and the United Kingdom (although the consequences of Brexit are uncertain) in service provision. Japan is traditionally the hub of the East Asian value chain, and its investments and demands for intermediate goods have helped foster the growth of the so-called Asian Tigers. Due to the extraordinary growth of China following Deng Xiaoping's reforms in 1978, China also gained prominence as a regional hub in the 1990's (especially in productive integration with the countries of the former Indochina) and is still seeking more capacity for innovation. The third country that gained prominence as an exporter of final goods to both the Asian region and the world as a whole was South Korea, a country that imported more than $50 \%$ of its Gross Domestic Product (GDP) in 2012 (as per World Bank data).

It is expected that Brazil, as the largest economy in Latin America, will play the role of the central economy for the process of productive and commercial integration in South America (but mainly Mercosur). In the next section, we analyze the commercial dimension of Mercosur from the 2000s on, highlighting primarization, which seems to be affecting the export baskets of the bloc.

\section{The decrease in Brazil's trade with Mercosur countries}

Brazilian trade with South America and Mercosur grew by more than $400 \%$ between 2002 ( $\$$ US 7 billion) and 2008 (US\$38 billion). Viewed in isolation from Brazil's trade with other regions, this growth could be seen as a big jump. However, Brazilian trade with other South American countries has shown a downward trajectory after 2011, as shown in Figure 02. This trade reached its peak in 2011, with more than US\$ 45 billion (summing together exports and imports), which at the time seemed to be a major recovery from the 2008-09 economic crisis. Meanwhile, the low levels of trade for the 
Brazil-Andean Community (CAN) ${ }^{1}$, which never exceeded US\$ 8 billion during this whole period of time, has decreased far less. As a result, the decline of Brazil's trade with other Mercosur countries is clearly the main component driving the decline in trade between Brazil and South America.

Figure 02. Brazilian foreign trade with South America, Mercosur, and CAN (Billions of US\$)

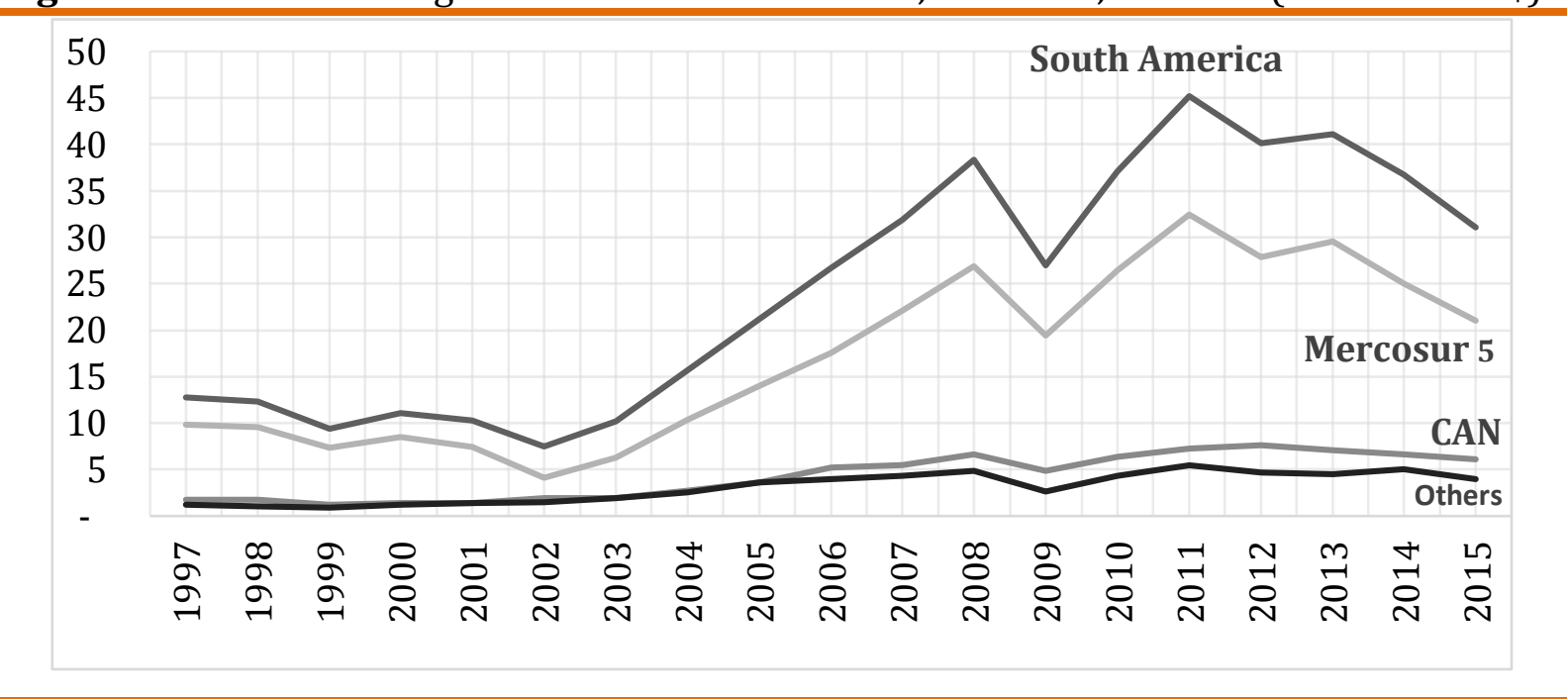

Source: MDIC, 2016.

When considering Brazilian trade with Mercosur and South America within total Brazilian trade, these exchanges never really reached the level recorded in the mid-1990s (Figure 03). The Brazilian exchange-rate crisis of 1999, the low market expectations due to the Lula's elections of 2002 and the collapse of the Argentine economy in 2001, are some of the main factors that explain the significant commercial decline around the turn of the 21 st century.

1 The Andean Community is a South-American bloc made up of Bolivia, Colombia, Ecuador, and Peru. Chile is inside the 'others' category. The Andean Community has lost some strategic importance as an integration bloc after the creation of the Pacific Alliance in 2011, which is made up of Chile, Colombia, Mexico and Peru, all of which are countries committed to free trade within the bloc and large, wide-ranging agreements. However, we use the term 'Andean Community' as it is still used in official Brazilian statistics, since our focus in this article is on Mercosur and South America, not necessarily its divisions, which will be addressed in other articles. 
Figure 03. Brazil's trade share with Mercosur and South America as compared to Brazil's total trade

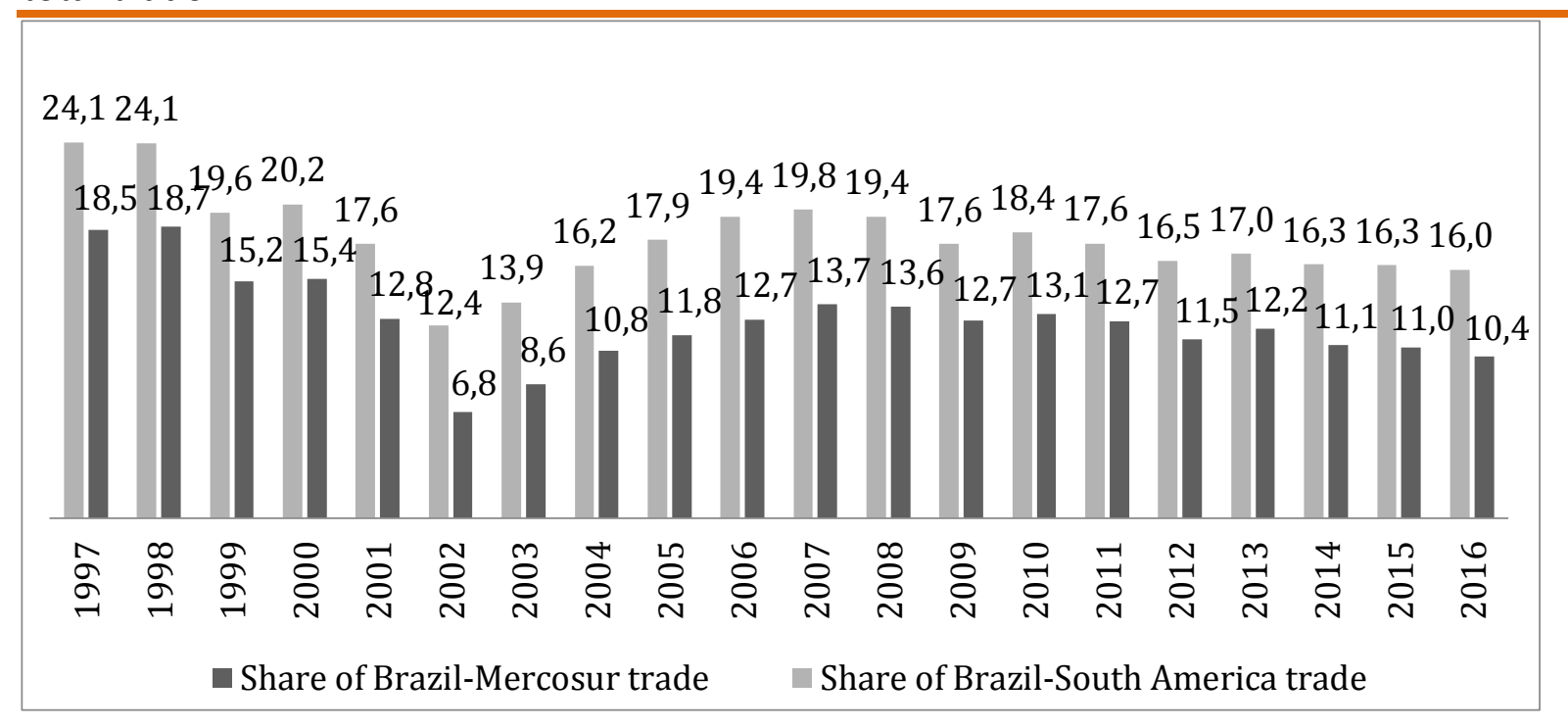

Source: MDIC, 2016.

Trade relations figures improved in the 2000s (at least until the international crisis of 2008), which seems to be related to the economic growth and increased purchasing power of countries. Since then, in convergence with the slowdown of trade (as shown in Figure 02), there has also been a downward trajectory in both Brazil-Mercosur and Brazil-South America trade as a percentage of Brazil's total trade (with the exceptions of 2010 and 2013). The weak performance of the Brazilian economy since 2011 has certainly been one of the main factors behind this tip in trade flows. Many economists have pointed to the low levels of productivity in the Brazilian economy (BACHA and BOLLE, 2013; CNI, 2015) as a factor behind the tip in Brazilian exports during this period, while some have also pointed to the appreciation of the Real in the second half of the 2000s. Likewise, China's entry into the WTO in 2001, which gave the country greater market access and value chain evolution - especially in East Asia - caused a shock in relative global prices, reducing manufacturers' prices thanks to high levels of supply, and increasing commodities' prices thanks to high demand. There has been an increase of competition in the South American market, which in part justifies the deceleration of trade and the reduction of Brazilian manufacturers' exportations in Mercosur and South America (JENKINS, 2015).

Given these macro-observations, the decrease in Brazilian trade with the region, in aggregated factor terms, shows evidence of a relative primarization. An aggregate 
factor $^{2}$ analysis shows a notable decline in Brazilian manufacturing exports to Mercosur countries after 2008, and especially after 2011, as illustrated in Figure 04. The rise of manufacturing exports between 2003 and 2008 was due to the Mercosur economies' recovery from the crisis at the turn of the century. In 2011, Brazil exported US\$27 billion to other Mercosur countries, but this value dropped to US\$17 billion in 2015. Moreover, the trajectory of manufacturing exports strongly tracks the overall decline in both BrazilMercosur and Brazil-South America trade trajectories (Figure 02), which suggests that these exports have been the main cause of the decline in regional trade.

Figure 04. Brazilian exports to Mercosur by aggregated factor

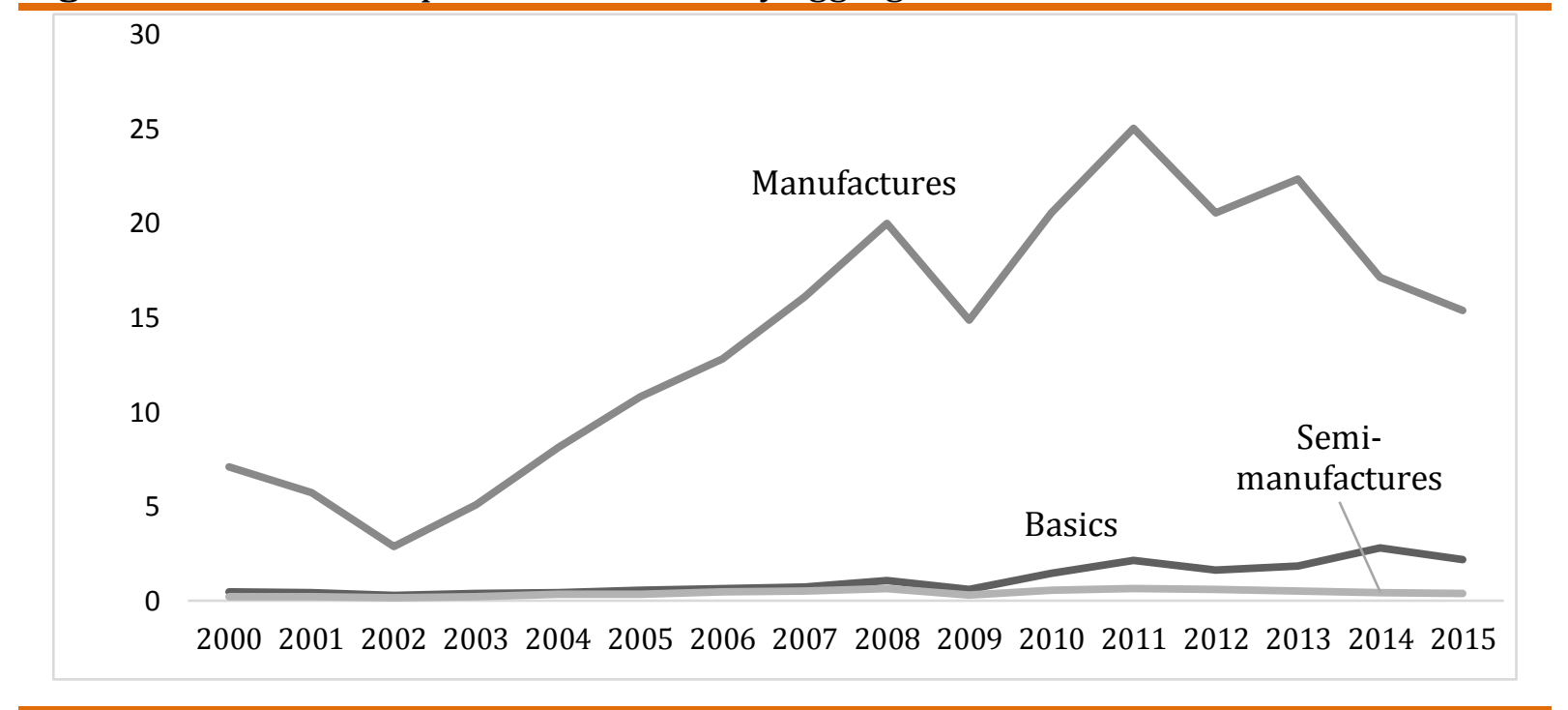

Source: MDIC, 2016.

As per MDIC data, in 2015, approximately $80 \%$ of Brazil's exports to South America, and around $86 \%$ of its exports to Mercosur (81\%, when including Venezuela) were manufactured goods. This percentage is much higher than it is for exports to other regions. In addition to geographic proximity, the preferential trade agreements within the Latin American Integration Association (ALADI) and Mercosur can explain this high concentration. Latin America absorbs more than a third of Brazilian manufactured exports. The regional market is central to Brazil's economy, but one must question the

\footnotetext{
2 We use 'aggregate factors' to analyze export components, as reported by Brazilian official statistics. Basic products are those that are close to the state in which they are found in nature, i.e., with a low degree of elaboration, such as mining and food products. Semi-manufactured products (such as raw sugar, semi-manufactured iron products, and pulp) are industrialized products that are not in their form of use, either final or intermediate, because they must go through another production process to become a manufactured product.
} 
long-term sustainability of these value-added exports because South America is a moderately small market in the context of global GDP.

When we consider this decline in trade, however, one could argue that a wideranging phenomenon is taking over the global economy. Low GDP growth and stagnant productivity in the developed world have led to some of these effects on emerging markets. A slight return to protectionism, a reduction in global investment, and even a possible peak in global value chain expansion could be behind the reduction of trade growth when compared to GDP growth (IMF, 2016). There is also the possible confound of a natural phenomenon; Al-Haschimi et al. (2016) argue that the strong trade growth before the 2008 crisis had been exceptional compared to other times, so the current dynamics could even be considered a 'great normalization of trade'. Factors such as changes in demand for less trade-intensive products and services, and more focus on domestic markets (especially in China and other emerging countries) could have been causing this reduction in global trade. In addition, given the low levels of trade barriers and transportation costs, there was always going to be a limit to trade expansion beyond the growth already achieved in previous decades.

Structural factors explain part of why exports declined in both Brazil and the other Mercosur economies. Figure 05 shows a downward trend in the value added of manufactured goods as a percentage of GDP for the five MERCOSUR countries. This drop was substantial in the 1990s, but began in the 'lost decade' of the 1980s, especially for Argentina, Brazil, and Uruguay. There were signs of recovery in Venezuela in the second half of the 1990s, and for the other four countries in the first half of the 2000s. However, with the small exception of 2014 and 2015 for Uruguay, it is possible to notice a trajectory of structural decline for manufacturers. What is even more interesting is the fact that Brazil also had the lowest manufacturing value-added in MERCOSUR in 2014 and 2015, with around $11 \%$ of value-added.

There are several hypotheses, which are not mutually exclusive , regarding the composition of the Mercosur economies. One of the factors behind this structural decline is the service sector's increase; with economic growth has come a trend of increasing domestic demand for the service sector, which in many areas is (as of yet) not tradable. Also, possibly due to new classifications of production much of what was being computed as manufacturing began to be considered as services. The second factor is related to the commodity price boom, which, in turn, was highly influenced by global dynamics. At least 
during the 2000s, Latin American economies were for the most part driven by trade profits from primary goods exports, which prospered at the expense of greater attention to the competitiveness of the manufacturing sector. A related third factor is prices. The relative reduction in manufacturing prices reduced the importance of the sector when compared to other sectors, especially services.

Figure 05. Manufacturing, value added (\% of GDP)

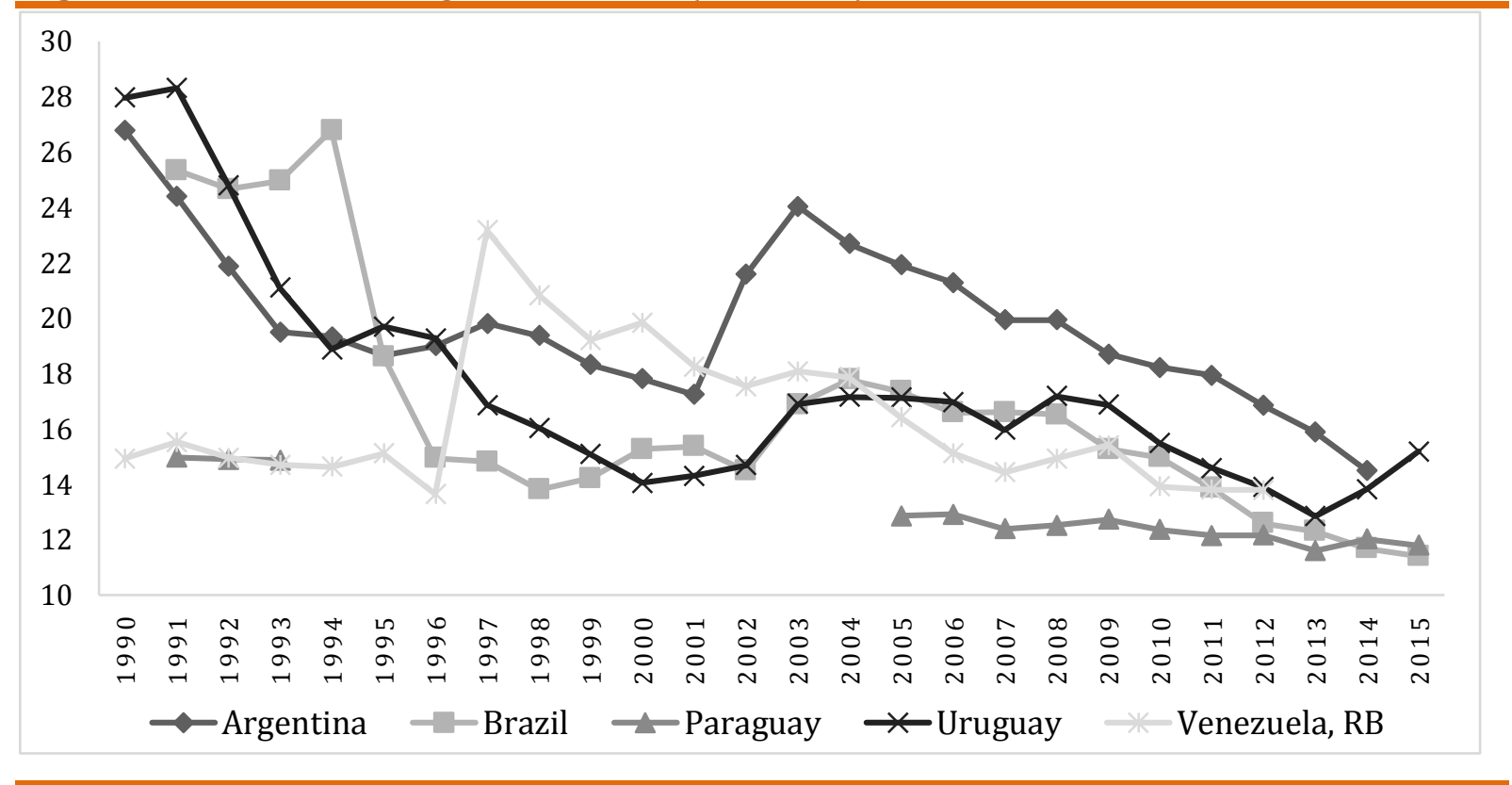

Source: World Bank, 2016.

Figure 06. Total manufacturing exports (\% of merchandise exports)

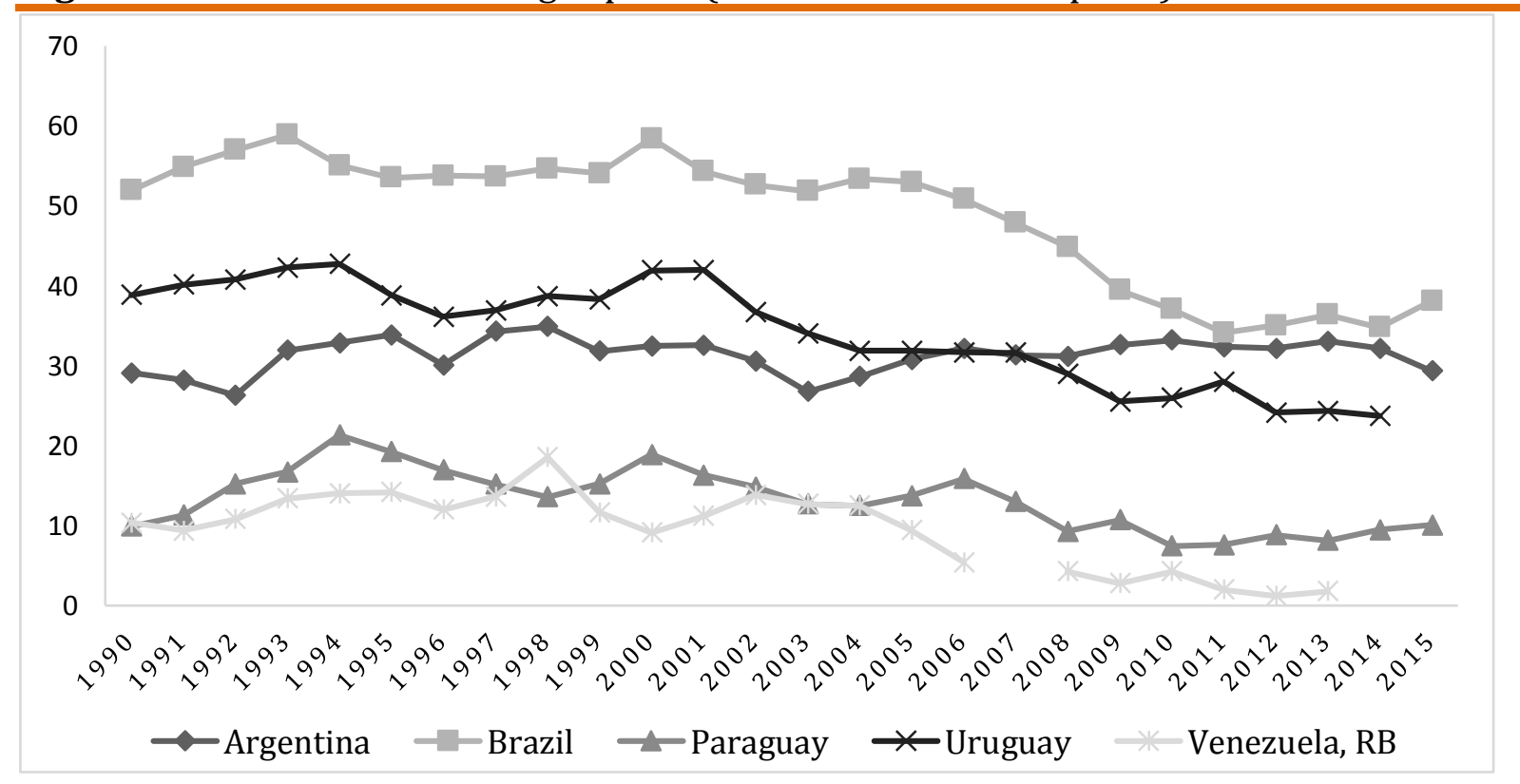

Source: World Bank, 2016. 
Despite being the country with the most diversified industry within Mercosur, since 2007, Brazilian exports of manufactured goods have accounted for less than half of Brazilian merchandise exports, a much sharper drop than in other Mercosur countries, as shown in Figure 6. It is possible that Brazil's low performance could reduce the potential for productive integration in Mercosur.

There are other factors that tend to support the argument that there has been a 'primarization' in Mercosur. In 2005, shortly before the boom in international commodity prices, manufacturing products accounted for $45.5 \%$ of the bloc's merchandise exports to the world and dropped to 26.3\% in 2014 (WT0, 2015). Excluding Venezuela from the calculations, the products that gained the most share of merchandise exports were fuels and mineral products (mainly because of a rise in oil prices), which represented $17.2 \%$ of global exports in 2005 and came to represent $24.8 \%$ in 2014. When considering exports 'between' Mercosur countries, there has still been a reduction in the share of manufactured exports, but much less steep than the total figure: in 2005 , they accounted for $67.5 \%$ of merchandise exports, while in 2014 , the share had fallen to $56.1 \%$.

Since Uruguay and Paraguay are small economies, the trade dynamics of Mercosur - and much of South America - has mainly been due to the performance of the Brazilian and Argentine economies, which we discuss in the next section.

\section{Brazil and Argentina and value-added trade dynamics}

Along with the development of value chains' over the last few decades, there has also been a proliferation of regional agreements, encouraging regionalism as well as globalization. Regional markets are traditionally a primary source of trade activity, and even with information and communications technologies - (ICT) advances, geographic proximity is still a valuable factor in the development of value chains since the degree of integration already existing between countries helps establish trust in international projects. Besides traditional trade statistics, the value-added approach provides insights into actual exchanges between economies within international production chains, as we can see in the cases of Brazil and Argentina.

In the traditional industrial sense, Argentina dramatically reduced its industry's share of GDP between 1974 and 2002. It is likely the most extreme example in the world of early de-industrialization, which came from an accumulation of 
economic and political crises. Nevertheless, being much less industrialized than Brazil at the end of the $20^{\text {th }}$ century, Argentina seems to have suffered less from deindustrialization than Brazil in the 2000s. The share of manufactured exports out of the country's total exports varied less, staying around 30\%. The participation of manufacturers in Argentine export baskets resulted in values close to those of Brazil in 2014, indicating that commodity prices exerted a greater effect on Brazilian exports than on Argentine exports, among other factors.

For Brazil and Argentina, exports of manufactured goods to Mercosur $668.2 \%$ and $66 \%$, respectively) in 2014 were double those to the world at large $(33.3 \%$ and $31.2 \%)$. This difference shows the importance of Mercosur for the manufactured goods exports of both countries-perhaps even a dependence. In this context, one must question the sustainability of these exports in a world undergoing great commercial and productive transformations, which demands greater competitiveness outside one's region. In this sense, it is important to be competitive in international terms in order to sustain national production, as is supported by East Asia's experience (BAUMANN, 2013; BHAGWATI and PANAGARIYA, 2013).

These changes include value-added trade, which has promoted value chains at the global and (increasingly) regional levels. With the fragmentation and dispersion of international production, exported and locally consumed products and services begin to contain more external elements, which reflects the degree of integration in today's global economy, especially for products with the most value added. One important expression of this integration is the degree to which gross exports are 'foreign valueadded', defined by the WTO as the "content of exports that corresponds to the value added of inputs that were imported to produce intermediate or final goods/services to be exported" (WTO, 2016, pp. 83). Figure 07 shows the foreign value-added share of gross exports to the 19 countries of the G20 - the 19 largest economies in the world, as well as the European Union - for 2011, the last year available through the TiVA database. We combined these figures with total imports as a share of GDP. 
Figure 07. Imports (\% of GDP) in 2015 and Foreign VA share of gross exports in 2011 (as $\%)$, G20 countries

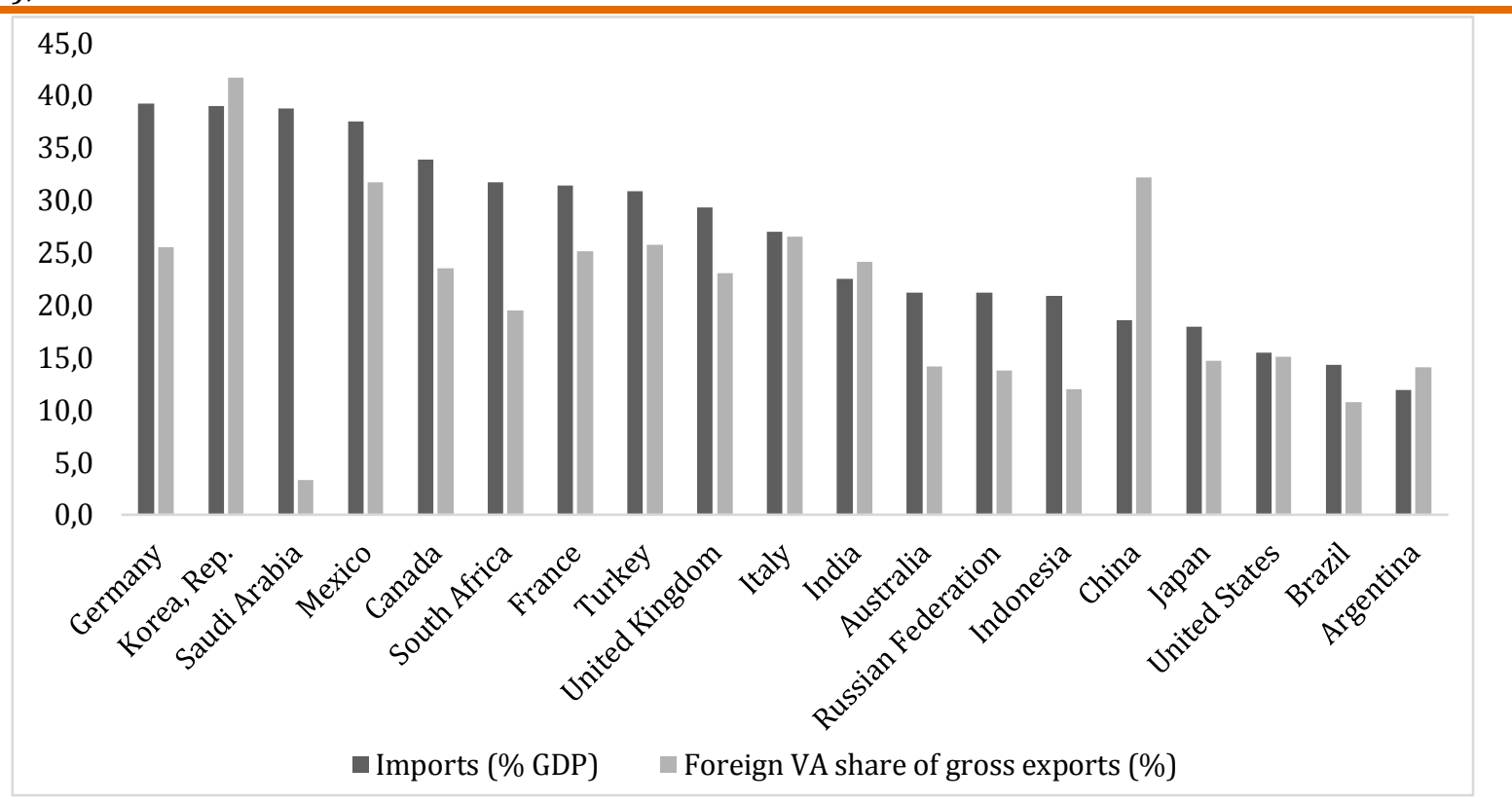

Source: World Bank data, 2016; OECD TiVA, 2015.

In 2015, out of the World Bank's ranking of 208 countries, Brazil and Argentina were only ahead of Sudan (10.9\%) and Nigeria (10.8\%) in the imports (\% of GDP) indicator. Among the G20, as shown in Figure 07, it is clear how the two countries are the most closed economies of the group, despite sharing a border and being the two most important economies in the most ambitious integration project among developing/emerging countries.

Even if it is not an indicator that necessarily guarantees exports' competitiveness, the value of the 'foreign value-added share of gross exports' expresses how closed the Brazilian and Argentine economies are, and how much they could gain from opening trade. In fact, foreign trade still represents a small share of both economies. The ratio of trade to GDP in 2015 was just 23\% for Argentina and 27\% for Brazil, while the world average was 57\%, according to World Bank data.

Figure 07 also suggests some patterns of participation. On the one hand, predominantly manufacturing economies tend to have higher foreign VA because products with high degrees of transformation tend to share more processes outside their home countries, particularly if the country is not close to the technological frontier. On the other hand, economies that focus more on exporting primary goods and fossil fuels, such as Australia, Russia, Indonesia, Saudi Arabia, Brazil, and 
Argentina, tend to have less foreign content added because primary goods production is a difficult process for 'international slicing'.

Besides the structure of the economy and the availability of natural resources, many factors influence the level of foreign VA for exports, such as the size of the domestic market and the physical distance to the great global economic centers. This all helps to explain the low foreign VA level for Brazil and Argentina. However, nationalistic policy decision such as local content rules, for example, which were instituted by both countries in the beginning of the 2010's, have also distorted the participation of foreign firms in local production, and may also have contributed to the low performance of manufacturers' exports.

The TiVA database divides the domestic value-added content of exports into three indicators: 01. Direct (the domestic value-added embodied in either final or intermediate goods and services, which is directly consumed by the importing country and therefore represents a one-to-one transfer of value-added with exported goods and services crossing borders only once); 02. Re-exported (the domestic value-added contained in intermediate goods exported to a first country, which re-exports them to a third country in other goods and/or services, therefore representing a one-to-many country transfer of value added when exported goods/services cross borders more than once); and 03. Re-imported (the domestic value-added of exported goods and/or services that are eventually re-imported by the country itself) (WT0, 2016).

Another taxonomy of economic integration relates to the 'direction' of trade and production flows: 'backward' and 'forward participation'. Backward participation relates to upstream links, i.e., the foreign value-added and inputs included in a country's exports. Forward participation has to do with domestic value-added and inputs included in 'other' countries' exports (OECD and WTO, 2016). Regarding the technological transformation of products and their complexity, backward participation of a country tends to imply more manufacturing, and require primary products from other countries.

As shown in Table 01, Brazil and Argentina both show high domestic valueadded in exports compared to a global average of around 75\% in 2011. There are interesting differences between the two countries concerning this; the domestic valueadded that is 're-exported' (i.e., the embedded exports in other countries' exports to third countries) are considerably larger for Brazil-24.5\% of total exports, slightly 
above even the world average of $24.3 \%$ - than for Argentina, which has $16.5 \%$. In other words, Brazil supports the global competitiveness of other countries though its 'forward participation' by exporting intermediate goods to other countries, which in turn export the final goods with high added value.

Table 01. Value-added content of Brazil's and Argentina's exports, 2011 (as \%)

\begin{tabular}{|c|c|c|c|c|c|c|}
\hline & \multicolumn{4}{|c|}{ Domestic } & \multirow[t]{2}{*}{ Foreign } & \multirow[t]{2}{*}{ Total } \\
\hline & Direct & Re-exported & Re-imported & Total & & \\
\hline Argentina & 69.4 & 16.5 & 0 & 85.9 & 14.1 & 100 \\
\hline Brazil & 64.6 & 24.5 & 0.1 & 89.2 & 10.8 & 100 \\
\hline World Average & 51 & 24.3 & 0.4 & 75.8 & 24.2 & 100 \\
\hline
\end{tabular}

Source: OECD Tiva, 2015.

Argentina has shown a more nationalist pattern in regards to direct domestic value-added. Although Brazil's total domestic value-added is higher than Argentina's, Argentina's exports include $69.4 \%$ of 'direct' domestic VA, while Brazil has $64.6 \%$. In addition to the application of local content, one of the factors that helps explain this difference is that Argentina has fewer minerals and fuels than Brazil, and these sectors tend to be processed as intermediary goods for producing final goods. The 'reimported' value is practically zero for both countries, reinforced by the fact that both countries' imports are a very small part of GDP, as shown in Figure 07.

Another way to illustrate these value-added data is displayed in Figure 08. Both Brazil and Argentina are below the average rate of participation in global value chains for both developed and developing countries. Argentina has more balance in its forward participation (re-exports in domestic value-added) and backward participation (foreign value-added), but in general, the country is below Brazil in this regard. In the Brazilian case, the very low backward participation rate seems contradictory for an economy that wanted to internationalize and export valueaggregate products, as was expressed in its plans for productive development policies.

The two most industrialized countries in South America, and the pillars of MERCOSUR integration, show marked differences regarding the two types of participation in value-added trade. As shown, Brazil does not import as many intermediate components and goods from other countries to add value to its exports (only around $10.7 \%$, less than the half of the average for developing countries). Meanwhile, its largest regional partner does not export as many components and 
intermediary goods that are incorporated into exports from other countries to third parties (only around 16, 4\%).

Figure 08. The GVC participation index, 2011 (as \%)

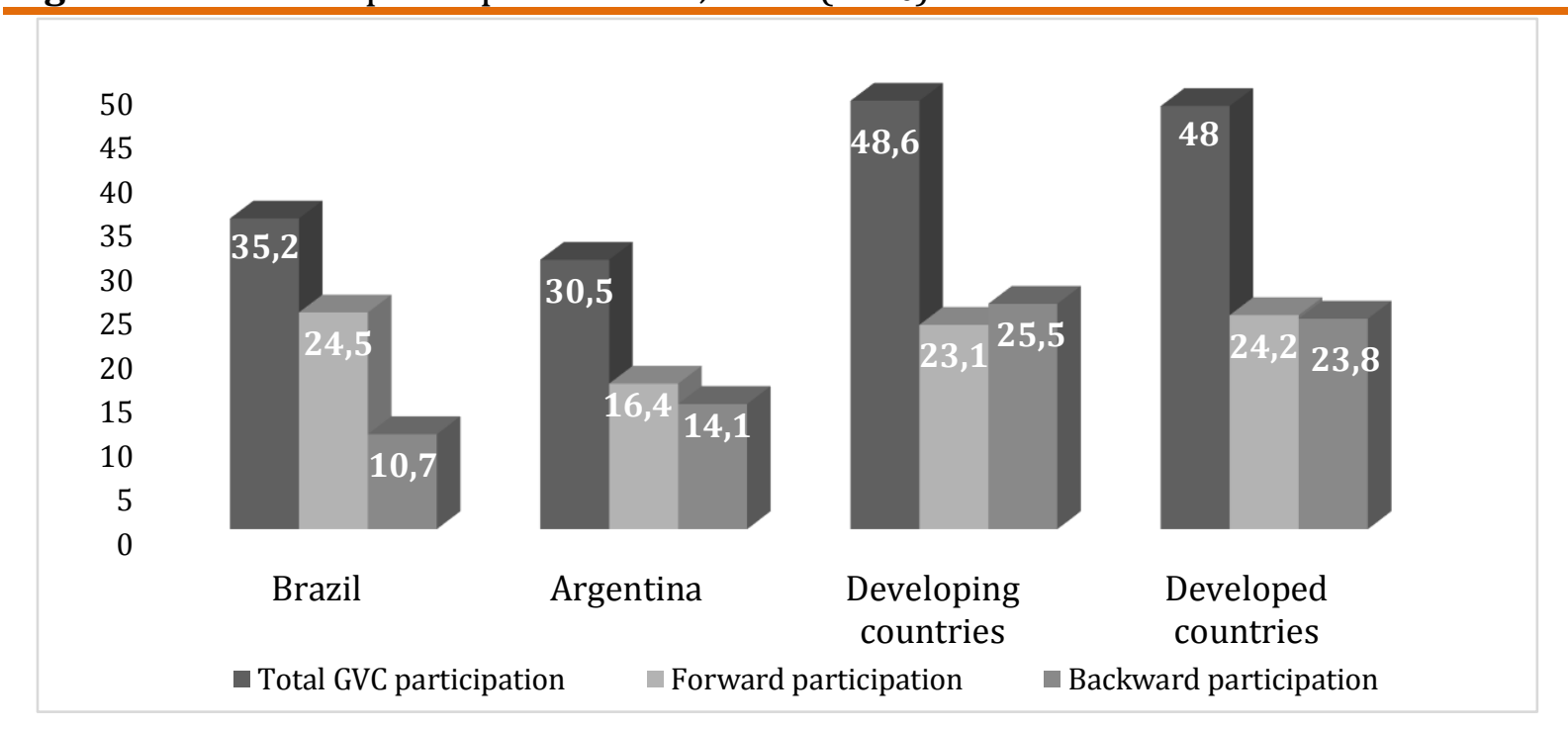

Source: OECD Tiva, 2015.

We argue that the logic of Brazil-Argentina integration, given the current trade flows and sizes of the economies, makes little sense regarding the rationale of value chains, which could threaten the trade sustainability of Mercosur. Concerning the productive logic in the formation of regional value chains, one would expect 'high levels of backward participation for Brazil', and 'high levels of forward participation for Argentina', as this process would guarantee greater productive integration and take advantage of the complementarities in their economies. The emphasis on exports' complementarity combined with harmonized business cycles was critical for East Asian countries to establish high levels of productive and trade integration, as well as reasonable levels of growth, over the last few decades.

However, this process would not be easy for Mercosur. Some commitment to reduce national sovereignty would be needed from both countries as they re-thought industrial autonomy and how to deal with special interests, which tend to favor protection from imports (even inside Mercosur). Likewise, following the regional value chain pattern, Brazil, as the larger economy, would be expected to play the role of the hub in the regional production process, and Argentina would play the role of a spoke. But when we are dealing with two very closed economies, as our evidence shows, a long-term plan oriented toward developing Mercosur could be a better 
option, with entrepreneurs participating, and governments enjoying less autonomy to implement their own national policies. Infrastructural and logistical investments would also play an important role in making those plans possible and decreasing transaction costs, which would require some convergence with Mercosur countries' policies.

In regards to the participation index, Tables 02 and 03 summarize many aspects of Brazil and Argentina's participation in value-added trade, providing important insights. For Brazil, the mining sector has the most active participation in the GVC, far surpassing other sectors, which was probably influenced by the commodity boom of the 2000s. Despite being one of the countries with the most competitive agricultural sectors in the global market, Brazil's mining sector is not among the three most active participants. For Argentina, however, which also is quite competitive, agriculture has a relatively more active role3. For both countries, mining and wholesale and retail trade stand out in terms of the value-added embedded in other countries' exports to third parties.

Table 02. GVC participation index, Brazil, 2011 (as \%)

\begin{tabular}{lclc}
\hline \multicolumn{2}{c}{$\begin{array}{c}\text { Forward GVC participation* } \\
\text { Top exporting industries to GVCs }\end{array}$} & \multicolumn{2}{c}{$\begin{array}{l}\text { Backward GVC participation** } \\
\text { Top GVC-importing industries }\end{array}$} \\
\hline Mining & 22.9 & Mining & 18.1 \\
Wholesale and retail trade & 15.4 & Food and beverages & 12.7 \\
Other business services & 12.2 & Basic metals & 9.4 \\
\hline \multicolumn{2}{c}{ Top exporters of Brazil's inputs through GVCs } & \multicolumn{2}{c}{ Top foreign input providers } \\
\hline China & 19.5 & United States & 17.2 \\
United States & 8.2 & China & 7.5 \\
Germany & 7.2 & Germany & 5.2 \\
\hline
\end{tabular}

Source: OECD Tiva, 2015.

Notes: $\left({ }^{*}\right)$ As a \% share of total exports of domestic inputs sent to third countries.

$\left.{ }^{* *}\right)$ As a \% share of total foreign content of exports.

${ }^{3}$ Of course, we are evaluating the percentage share, not necessarily the absolute value, which is much larger for Brazil.

(2017) $11(3) \quad$ - 
Table 03. GVC participation index, Argentina, 2011 (as \%)

Forward GVC participation

Top exporting industries to GVCs
Backward GVC participation

Top GVC-importing industries

\begin{tabular}{lclc}
\hline Mining & 17.3 & Motor vehicles & 21.5 \\
Wholesale and retail trade & 15.7 & Food and beverages & 18.7 \\
Agriculture & 13.7 & Agriculture & 10.7 \\
\hline \multicolumn{1}{c}{ Top exporters of Argentina's inputs through GVCs } & \multicolumn{2}{c}{ Top foreign input providers } \\
\hline China & 12 & Brazil & 24.4 \\
Canada & 9.3 & United States & 13.8 \\
Chile & 7 & China & 5.9 \\
\hline
\end{tabular}

Source: OECD Tiva, 2015.

The absence of more technologically complex sectors in backward participation for Brazil and Argentina should warrant greater attention. Motor vehicles are first out of all Top GVC-importing industries in Argentina, which is one of the exceptions to the productive integration of Mercosur. Some authors draw attention, however, to the protective role of the Common Custom Tariff, which was adopted by Mercosur as a 'market reserve' guarantee, especially for the automotive market. Despite encouraging regional trade, this protectionism would hamper global competitiveness because automotive production in Mercosur is not well-integrated with the rest of the world (BONOMO, 2014; CANUTO, 2014). In this context, Kamiya (2014) conducted a study on 'revealed comparative advantage (RCA)' of Brazilian industries. First, he found that, although production sharing in Brazil has increased over the past two decades, the process has been a straight upward trend (i.e., networks have not been built). Second, he found that the strength of Brazilian trade in manufactured goods "may not be based on competitiveness, but rather on other factors resulting from domestic market size, MERCOSUR membership, and production development policies targeting the electronic, automotive and aircraft industries" (KAMIYA, 2014, pp. 238). Moreover, in line with our conclusions above, "in the automotive industry, higher relative RCA may be the result of market protection measures between MERCOSUR member countries, so trade with Argentina is not the result of competitiveness" (KAMIYA, 2014, pp. 237-238).

Despite being the third-largest recipient of Brazilian exports in traditional trade, Argentina is not among the top three exporters or importers for Brazil in value-added terms. In addition to being the largest destination for Argentine exports in 2011, Brazil is 
the largest supplier of components and intermediate goods for the Argentine market, with almost a quarter of foreign inputs. Notably, another regional partner of Argentina, Chile, is the third-largest exporter of Argentina's inputs though GVCs. Brazil appears to have a dynamic relationship with the United States, China, and Germany, which are also top exporters of Brazil's inputs and top providers of foreign input. This shows that Brazil and Argentina - given their geographic proximity and the size of their economies - could use Mercosur's incentives and traditional margins of trade to redirect trade flows toward building regional production networks, such as trade in parts for the electronics and computer industries. They could also, for example, make the automotive industry more outward-oriented. In this regard, research measuring the complementarities of specific industry sectors should indeed be conducted.

Table 04. Weighted average tariff (\%) on imports of intermediate goods (effectively applied)

\begin{tabular}{|c|c|c|c|c|c|c|c|c|c|c|c|c|}
\hline & 2005 & 2006 & 2007 & 2008 & 2009 & 2010 & 2011 & 2012 & 2013 & 2014 & 2015 & $\begin{array}{c}\text { Period } \\
\text { Average }\end{array}$ \\
\hline Venezuela & 9.9 & 7.4 & 9 & 9.9 & 8.8 & 8.3 & 9.1 & 9.4 & 9.2 & - & - & 9 \\
\hline Brazil & 6.2 & 6 & 5.9 & 5.6 & 6.4 & 6.8 & 6.7 & 6.7 & 8.1 & 6.9 & 6.7 & 6.5 \\
\hline $\begin{array}{l}\text { Argentina } \\
\text { Latin }\end{array}$ & 4.6 & 4.4 & 4.5 & 4.6 & 4.9 & 4.9 & 4.9 & 5.3 & 5.4 & 5.5 & 5.7 & 5 \\
\hline $\begin{array}{l}\text { America \& } \\
\text { Caribbean }\end{array}$ & 4.5 & 4.1 & 4.1 & 4.1 & 3.8 & 5.4 & 5.1 & 5.2 & 5.4 & 3.4 & 5.2 & 4.6 \\
\hline World & 5.3 & 5 & 4.5 & 4.2 & 4.2 & 4 & 4 & 3.6 & 3.7 & 3.2 & 3 & 4.1 \\
\hline Uruguay & 4 & 3.2 & 3.6 & 3.3 & 2.9 & 3.7 & 3.6 & 3.3 & 4 & 4 & 4.1 & 3.6 \\
\hline $\begin{array}{l}\text { East Asia } \\
\text { \& Pacific }\end{array}$ & 4.4 & 3.9 & 3.7 & 3.4 & 3.3 & 3.2 & 3.1 & 2.3 & 2.4 & 2.6 & 2.6 & 3.2 \\
\hline Paraguay & 2.5 & 1.2 & 1.8 & 2.4 & 2.4 & 2.5 & 2.6 & 2.8 & 2.8 & 3 & 3.3 & 2.5 \\
\hline $\begin{array}{l}\text { European } \\
\text { Union }\end{array}$ & 2.5 & 2.4 & 1.8 & 1.6 & 1.7 & 1.8 & 1.6 & 1.2 & 1.3 & 1.8 & - & 1.8 \\
\hline $\begin{array}{l}\text { North } \\
\text { America }\end{array}$ & 1.2 & 1.1 & 0.9 & 1.1 & 1.3 & 1.2 & 1 & 0.9 & 0.9 & 1 & 0.9 & 1 \\
\hline
\end{tabular}

Source: World Bank, 2016.

Furthering the logic of forming and advancing value chains when seeking productive complementarities, the trade of intermediate goods - which are consumed during the production process and produce final goods - play an important role in reducing production costs and, therefore, in increasing industrial competitiveness. The evidence, however, shows that Brazil and Argentina have implemented tariff policies that do not agree with this logic. Table 04 shows the weighted average tariff rate on imports of intermediate goods by region. Countries and regions are ranked in descending order, according to the average rate adopted between 2005 and 2015 . 
It is clear that the three regions that are most integrated regarding production and trade are also the ones that adopt the lowest weighted average tariffs for intermediate goods. Except for Paraguay and Uruguay, the average rate adopted by the other three MERCOSUR countries was above the world average of $4.1 \%$ over the same period, and even above the Latin American and Caribbean averages. Latin American countries, including the four original Mercosur countries, had higher tariffs in 2015 than in 2005. Conversely, the three regions that are most integrated, as well as the world average, have shown a downward trajectory in adopting tariffs.

Besides all the 'material' questions analyzed, structural changes in the global economy made the competitiveness of the services sector more important in comparison to other sectors, becoming an almost inseparable part of many manufacturing segments, especially for advanced manufacturing. The logic of value chains, whether global, regional, or national, shows that in many production processes, the value-added concentrates the most in the services sector, both in pre-production (such as research and development) and post-production stages (such as marketing) (OECD, 2013).

The push for globalization by various economies through foreign direct investment, trade promotion, technology diffusion, and political openness in the 1990s helps us understand part of the decline in the value-added concerning traditional manufacturing. Advanced economies have specialized in R\&D, innovation, concept and product design, and marketing services, while many production and assembly activities have moved to countries and regions that offered tax benefits and advantages in low-cost production. These innovation advances are some of the factors that could make one argue that de-industrialization is not taking place in advanced countries because service sector appreciation (many of services being tradable across international borders) is a key variable in the reducing the portion of GDP destined to manufacturing in market price terms.

Services make up a considerable share of total exports for the world as a whole, and for Brazil and Argentina, the value-added content of service exports diverge from this pattern once again. Brazil has a large share of domestic services in both types of aggregated exports, while Argentina adds more foreign value (Figure 09). As for the supply of components and intermediate goods (Table 03), Brazil is the largest provider of services for Argentine exports, both for total exports and manufacturing exports. For Brazil, the United States is the main supplier of services for exports. 
Figure 09. The services value-added content of exports, by origin, 2011 (\% shares in manufacturers and total exports)

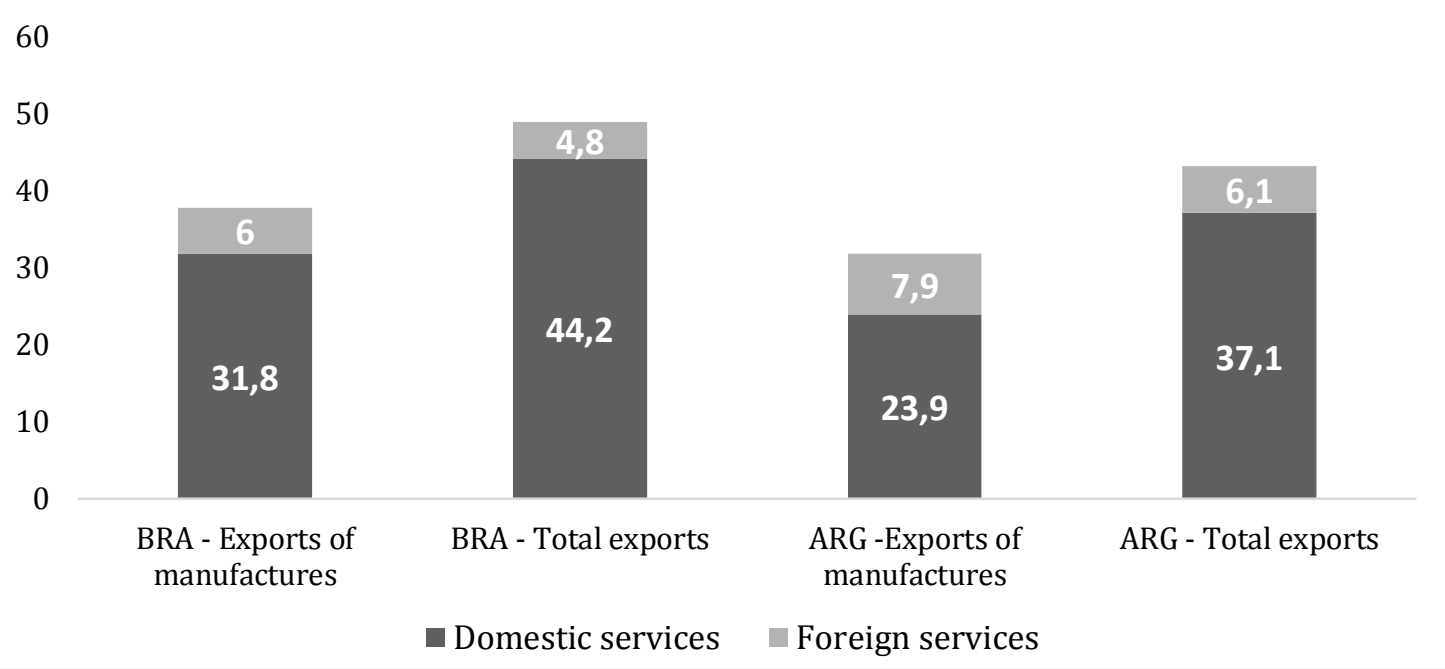

Source: OECD Tiva, 2015.

Figure 10. Trade Blocs by Exporting and Importing in 2015 (as \% of global trade of services)

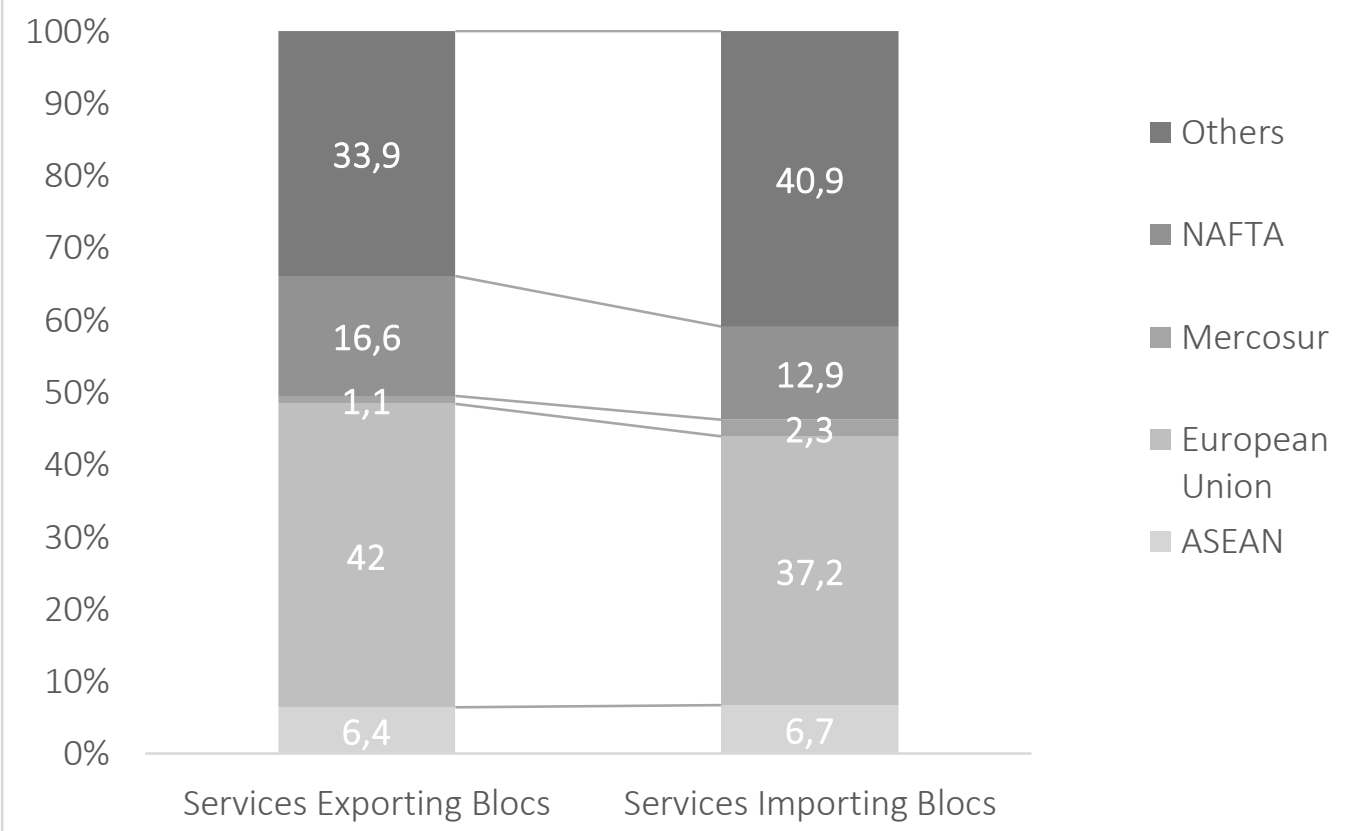

Source: MDIC (2016).

It is key that both Brazil and Argentina work to promote the services sector in a synergistic way, both within individual economies and the region; this could increase Mercosur's low rate of participation (of $1.2 \%$ of global totals) exports. Clearly in deficit, Mercosur represented 2.6\% of world imports in 2015 (Figure 10).

According to the Ministry of Development, Industry and Foreign Commerce (MDIC), Brazil was only 31st in the world in service exports in 2014, with a $0.8 \%$ share of 
world exports. For imports, Brazil ranked 17 th for services, with a share of $1.8 \%$ of world imports. Considering the aggregation of value in a chain, as shown in the Smiling Curve from Figure 01, nations that produce specialized services and combine them with the manufacturing sector tend to be more competitive internationally and have greater shares of gains. In this sense, more complex nations in NAFTA and the European Union are the most representative trading blocs in world trade in services, which is another indicator of their international competitiveness.

Arbache (2016) has shown that although industry and services go hand in hand, and Brazilian intermediate service consumption is similar to how it is in advanced economies, there is little evidence that services have helped increase Brazilian competitiveness. If anything, it has been the reverse; most services in the Brazilian economy are of low quality and high cost, increasing the costs of industrial production. The prospects for expanding the use of the digital economy also show the high potential for restructuring economies, thereby providing opportunities for Brazil to improve its economy. The agricultural sector, which is a strong component in both the Brazilian and Argentine economies, could add services and obtain greater gains from global trade, in addition to exploiting natural resources. This is a strategy carried out by the European Union, which stands out both in the agricultural sector and in services, being the main exporting bloc of services in 2015.

\section{Mercosur as a model of 'introspective' integration}

After showing Mercosur's low levels of performance in manufacturing and services, and analyzed different countries' profiles, our results mesh with what is found in the literature about Mercosur, particularly about its integration of trade and production concerning the value chains logic.

In this regard, Ferraz, Gutierre and Cabral (2015) put together triangulation tables comparing Mercosur with other regional value chains such as NAFTA, the European Union, and the would-be Trans-Pacific Partnership. They found that Mercosur countries are poorly integrated in relation to the logic of regional supply chains. According to them, levels of "'reflection' (the re-export of imported intermediates back to the country of origin after they have been re-processed in a foreign country) and 're-direction' (the reexport of the imported intermediate good to third countries) are relatively low for 
regional trade among countries in Mercosur" in comparison to other regional or global value chains (FERRAZ, GUTIERRE and CABRAL, 2015, p. 15).

Using network analysis, Iapadre and Tajoli (2014) show some patterns of trade regionalization. According to them, the relations between the 'hub' (largest economy) and the 'spokes' (smaller economies) establish two main standards of leadership: those of 'export hubs' and 'local suppliers'. The export hub model arises when the preference of the larger economy (hub) for intra-regional trade is higher for imports than for exports, which "can be the result of regional production networks, in which final products made of inputs produced in different spokes are exported by the hub country to the rest of the world" (IAPADRE and TAJOLI, 2014, p. 95). Otherwise, the local supplier model is a more 'inward-looking' regional integration pattern, in which the countries' aspirations for competitive global insertion becomes a more difficult task. For hubs in the local supplier pattern, intra-regional trade preference is higher for exports than for imports. According to the authors, "[t]his can be the result of the leader country attracting FDI and related imports of intermediate goods, which are used to produce final goods for the entire regional market" (IAPADRE and TAJOLI, 2014, p. 95). Brazil has a leadership pattern closer to the dominant 'local supplier' model because Mercosur has been largely built around Brazil's capacity to export to the region. Brazil, however, is not as big an importer in the regional context, while its exports appear to be "fed by imports coming predominantly from the rest of the world" (IAPADRE and TAJOLI, 2014, p. 107).

As Baumann (2013) points out, in East Asia, there's a 'regional multiplier effect', which assumes the existence of a mechanism of derived demand. In this model corresponding to the export hub model - an increase in countries' demands (in general, hubs) for final goods generates an automatic increase in demand for intermediate and capital goods of other neighboring countries (in general, spokes). In other words, an increase in global demand for the 'hub's final' goods leads to an increase in demand for inputs from the spokes, producing a virtuous cycle of production. Nevertheless, in South America, there is an inverse flow of intermediate goods, where large economies export production goods to other neighboring economies and import primary goods from them, such as in the case between Brazil and Paraguay (BAUMANN, 2013).

The success of the integration of East Asia - a similar region to South America in terms of underdevelopment until to the 1980/90s - demonstrated in part that if integration were to take place in practice, the gradual elimination of trade barriers would 
be necessary. In terms of economic foreign policy, East Asian countries also turned to developed markets, especially to the United States. Furthermore, East Asia, even suffering for a long time from an "organizational and institutional gap" (CALDER and FUKUYAMA, 2012), obtained a high degree of economic and productive interdependence, becoming one of the three great poles of productive chains in the world. In contrast, Latin America, which has a long history of regional institutions, has promoted development policies almost strictly at the national level, far detached from virtuous commercial, financial, and productive integration.

Some geographic aspects should be highlighted, as they can be decisive for effective regional integration. South America has geographical features such as the Andes Mountains, and natural obstacles such as the Amazon Forest, which make it complex to implement a project in the mold of the IIRSA (Initiative for the Integration of Regional Infrastructure in South America). Likewise, such a project demands more concern for environmental impacts when executing infrastructure projects, as well as the impacts on local communities. Meanwhile, some East Asian countries are separated (and linked) by seas, which reduces transport costs and encourages the construction of large and efficient port areas. As a result, in the case of South America, deficiencies in terms of infrastructure, in addition to geography, are important obstacles to the construction of regional value chains. Due to the distance between economic capitals in South America, which tend to concentrate most of the region's production and economic activity, the long-term perspective on the region's physical integration is even more important for paving the way to take advantage of complementarities between states.

Therefore, all the patterns discussed - the low levels of triangulation in Mercosur; the role played by Brazil as dominant local supplier, but not an export hub to third markets; and the absence of a regional multiplier effect - help to explain the relatively high concentration of Brazilian manufacturing exports in regional markets, as well as the relatively poor integration between Brazil and Argentina. It also goes a ways toward explaining the low performance of Mercosur's manufacturing exports. Mercosur's trade integration model does not guarantee trade sustainability in the long term, and increases the opportunity costs of generating employment and income within the bloc. Given the evidence, we call the current model of integration in Mercosur an 'introspective pattern'.

Summarizing what we have found, we note that there is a declining trend in manufacturing exports in Mercosur, which is reinforced by a China effect. Some aspects 
related to competitiveness and policy, however, also play key roles. The hypothesis of primarization is a danger for Mercosur economies, as it would make them more exposed to fluctuations in world markets, particularly in prices for engendered commodities and primary goods. Also, Mercosur (and by extension, South America) are important reserves of manufacturing exports for Brazil and Argentina, so the lack of competitiveness of both countries also is present in Mercosur.

Brazil and Argentina are still very closed to trade in comparison to other large countries, as shown by their low percentage of imports to GDP and the low foreign valueadded in gross exports. They are also integrated in an inward manner, which contributes less to joint competitiveness in world markets than it otherwise would. Mercosur's introspective pattern of integration is divergent from what is observed in the logic of value chains, as shown by the lack of outward-oriented regional networks. In addition, tariff levels combine with intermediate goods imports in a different way than what is observed elsewhere in the world. As we observed, services could play a crucial role in making Mercosur more competitive.

All this evidence shows some reasons why Mercosur countries are poorly integrated and have not increased their potential and survival capacity in global trade. Much research needs to be done about manufacturing performance, including output (in constant terms and productivity) and the role of exchange rates in re-primarization. There are also many other variables that could explain the lack of integration in Mercosur, particularly with sectoral analysis. Nonetheless, this article aims to contribute to the contemporary analysis of Brazil and Argentina and increase debate about the integration of Mercosur, a trading bloc that could be a mechanism for increasing joint competitiveness, but as of yet still is not.

\section{Final Considerations}

After more than six decades of efforts to promote regional integration, Latin America still has a lot of work ahead of it to see major economic breakthroughs. The consistent evaluation of the economic gains from policies of joint competitiveness is needed in order to improve the intensity and quality of integration.

The high domestic content in Brazil and Argentina's exports reflects the countries' low participation in international processes of productive complementarity, as well as large domestic restrictions on imports. The fact that both countries have not 
adapted to changes in the global economy may incur high opportunity costs, especially for the manufacturing sector.

The regional market has played an important role in Brazilian manufacturing exports, but the sluggish performance since 2011 deserves special attention. Despite making up an integration project that goes beyond the commercial area, Mercosur's goal of constructing a Common Market has progressed partially in the areas of social and cultural integration, but is still far behind economically. Furthermore, there has been an absence of effective institutional mechanisms for adopting supranational economic integration through productive complementarities. Overcoming trade (and political) barriers will largely depend on the main regional leaders and the degree to which the countries of the region can build a consensus between civil society, entrepreneurs, national governments, and, in the case of Brazil and Argentina, the subnational governments of the biggest states and provinces.

Mercosur also faces institutional difficulties, many of them due to the strong reluctance of Brazil and Argentina to partially abdicate national sovereignty to the integration project, as evidenced by the demonstrated high degree of closure of both economies. Macroeconomic difficulties were, and to some extent, still are, obstacles to progress in integration both inside and outside the bloc. Increasing trade in value-added also requires greater emphasis on regional trade agreements that insert 'new issues' into their projects far beyond tariff reductions, such as services, government procurement, intellectual property rights, and sustainability standards.

Brazil must work to reduce its own asymmetries as well as the asymmetries between Mercosur countries, both of which are factors that hinder integration. We believe, however, that these actions require structural integration, the harmonization of business cycles, productive complementarity, and greater attention to services as a source of competitiveness. The FOCEM - Fund for the Structural Convergence of Mercosur-has been insufficient for dealing with the reduction of asymmetries, thanks mostly to its extremely poor budget for addressing historical inequalities. Perhaps encouraging regional value chains to improve economic competitiveness could be an alternative to economic growth in the region, as well as job creation and long-term social prosperity.

One problematic factor is that Brazil and Argentina are rethinking part of their protectionist policies and becoming more politically engaged in opening up commercially to the world, but at a time when the economy and global trade are growing slowly 
compared to in previous decades, and nationalist-protectionist movements have been rising in developed economies. All of this increases the importance of Brazil and Argentina working together to find economic complementarities.

Nevertheless, we have two central observations to make. First, there is some evidence that global value chains seem to have 'peaked', just like global trade itself, in 2012. Second, new production technologies, such as 3D printers and second-generation robotics, make it more plausible that countries could bring back some stages of the production process back home (BRYNJOLFSSON, McAFEE, and SPENCE, 2014). These first two facts make GVC evolution somewhat more uncertain, as well as the possibility of some disruption, which could make regional value chains more feasible. We would like to stress, however, that this is a not a reason for Mercosur countries to not make progress in integration, as the pattern of integration could be transformed quite soon. Most of the time, there is a big price to pay for not following the tendencies of the global economy. What is a new pattern can become obsolete faster than it takes for decision makers' perceptions to change, especially in such a complex world.

Lastly, the fact that South American countries have shown low rates of GDP growth since 2013 could be related to the relatively low participation of more valueadded products in their export baskets, as manufacturing and services. As we showed, regional integration can be an important source of industrialization, mainly for developing countries, which could enjoy a comparative advantage in searching for productive complementarities in order to become more competitive on the global market. Without returns of scale, the manufacturing sector might not even survive.

Revised by Ryan Lloyd Submitted on December 09, 2016 Accepted on July 12, 2017

\section{References}

AL-HASCHIMI, Alexander; GÄCHTER, Martin; LODGE, David, and STEINGRESS, Walter(2016), The great normalisation of global trade. VOX CEPR's Policy Portal. Available at < http://voxeu.org/article/great-normalisation-global-trade>. Accessed on May 17, 2017.

ARBACHE, Jorge (2016), The contribution of services to manufacturing competitiveness in Brazil. In: Innovation and internationalization of Latin american services. Edited by HERNÁNDEZ, René; HUALDE, Alfredo; MULDER, Nanno, and SAUVÉ, Pierre. Santiago: ECLAC. pp. 65-98. 
BACHA, Edmar and BOLLE, Monica Baumgarten de (Ed) (2013), O futuro da indústria no Brasil: desindustrialização em debate. Rio de Janeiro: Ed. Civilização Brasileira. 420 pp..

BALDWIN, Richard (2011) Trade and industrialisation after globalisation's 2nd unbundling: how building and joining a supply chain are different and why it matters. NBER Working Paper № 17716. Cambridge: National Bureau of Economic Research.

BALDWIN, Richard (2013), Global supply chains: why they emerged, why they matter, and where they are going. In: Global value chains in a changing World. Edited by ELMS, Deborah K. and LOW, Patrick. Geneva: WTO Publications. pp. 13-60.

BAUMANN, Renato (2013), Integração regional: teoria e experiência Latino-americana. Rio de Janeiro: LTC. 268 pp..

BHAGWATI, Jagdish and PANAGARIYA, Arvind (2013), Why growth matters: how economic growth in India reduced poverty and the lessons for other developing countries. New York: Public Affairs. 304 pp..

BONOMO, Diego (2014), Sem deixar a peteca cair: o Brasil e os contenciosos na OMC. International Centre for Trade and Sustainable Development. Vol. 10, № 06, pp. 04-08.

BRYNJOLFSSON, Erik; McAFEE, Andrew, and SPENCE, Michael (2014), New world order: labor, capital, and ideas in the power law economy. Foreign Affairs. Vol. 93, № 04.

CALDER, Kent E. and FUKUYAMA, Francis (2012), Multilateralismo na Ásia Oriental: perspectivas para a estabilidade regional. Rio de Janeiro: Rocco. 335 pp..

CANUTO, Otaviano (2014), Why Brazil should embrace global value chains. World Economic Forum. Available at <https://www.weforum.org/agenda/2014/11/whybrazil-should-embrace-global-value-chains/>. Acessed on May 17, 2017

CONFEDERAÇÃO NACIONAL DA INDÚSTRIA (2015), Competitividade Brasil 2014: comparação com países selecionados. Brasília: CNI. Available at <http://www.portaldaindustria.com.br/cni/publicacoes-eestatisticas/estatisticas/2015/01/1,42616/competitividade-brasil-comparacaocom-paises-selecionados.html>. Accessed on November 20, 2015.

ECLAC (2014), Regional integration: towards an inclusive value chain strategy. Santiago: United Nations. 117 pp..

ELMS, Deborah K. and LOW, Patrick (Ed) (2013), Global value chains in a changing World. Geneva: WTO Publications. 436 pp..

ESTEVADEORDAL, Antonio; BLYDE, Juan, and SUOMINEN, Kati (2013), As cadeias globais de valor são realmente globais? Políticas para acelerar o acesso dos países às redes de produção internacionais. Revista Brasileira de Comércio Exterior. № 115, pp. 0625. 
FERRAZ, Lucas P. do C.; GUTIERRE, Leopoldo, and CABRAL, Rodolfo (2015), The manufacturing industry in Brazil in the era of global value chains. Fundação Getúlio Vargas. Escola de Economia de São Paulo. Working Paper № 402.

HERNÁNDEZ, René A.; MARTÍNEZ-PIVA, Jorge Mário, and MULDER, Nanno(Eds) (2014), Global value chains and world trade: prospects and challenges for Latin America. Santiago: Economic Comission for Latin American and the Caribbean. 282 pp..

IAPADRE, P. Lelio and TAJOLI, Lucia (2014), Emerging countries and trade regionalization: a network analysis. Journal of Policy Modeling. Vol. 36, pp. 89-110.

IMF (2016), Global trade: what's behind the slowdown? In: IMF. World Economic Outlook: subdue demand: symptoms and remedies. Washington: International Monetary Fund. pp. 63-119.

JENKINS, Rhys (2015), Is Chinese competition causing deindustrialization in Brazil? Latin American Perspectives. Vol. 42, № 06, 42-63.

KAMIYA, Marco (2014) Brazilian production sharing and implication for production integration in South America. In: Global value chains and world trade: prospects and challenges for Latin America. Edited by HERNÁNDEZ, René A.; MARTÍNEZ-PIVA, Jorge Mário, and MULDER, Nanno. Santiago: Economic Comission for Latin American and the Caribbean. pp. 207-244.

MDIC (2016), Panorama do Comércio Internacional. Dados de 2015. Brasília: MDIC. Available at <http://www.mdic.gov.br/comercio-servicos/estatisticas-do-comercioexterior-de-servicos/717-estatisticas-do-comercio-exterior-de-servicos-2015> Accessed on November 30, 2015.

OECD (2013), Interconnected economies: benefiting from global value chains. OECD Publishing. Available at <http://dx.doi.org/10.1787/9789264189560-en>. Accessed on February 20, 2017.

OECD and WTO (2016), Trade in value added (TiVA) database. Available at $<$ http://www.oecd.org/sti/ind/measuringtradeinvalue-addedanoecdwtojointinitiative.htm>. Accessed on December 01, 2016.

OECD; WTO, and UNCTAD (2013), Implications of global value chains for trade, investment, development and jobs. August. Paper prepared for the G-20 Leaders Summit Saint Petersburg (Russian Federation). Available at <http://www.oecd.org/sti/ind/G20-Global-Value-Chains-2013.pdf >. Accessed on November 30, 2016.

STURGEON, Timothy; GEREFFI, Gary; GUINN, Andrew, and ZYLBERBERG, Ezequiel (2013), o Brasil nas cadeias globais de valor: implicações para a política industrial e de comércio. Revista Brasileira de Comércio Exterior. № 115, pp. 26-41.

WORLD BANK (2015), Global Value Chains. Brief. Available at <http://www.worldbank. org/en/topic/trade/brief/global-value-chains $>$. Accessed on November 20, 2016. 
WTO (2015), International trade statistics 2015. Available at <https://www.wto.org/ english/res_e/statis_e/its2015_e/its2015_e.pdf>. Accessed on February 01, 2017.

WTO (2016), World trade statistical review 2016. Available at <https://www.wto.org/ english/res_e/statis_e/statis_e.htm>. Accessed on February 01, 2016. 